\title{
Interview
}

\section{In conversation with Enoch Powell (Minister of Health, July 1960-October 1963)}

Hugh Freeman interviewed the Rt Hon J. Enoch Powell at his home in London on 19 February 1988.

HF I would like to ask how you saw the mental health services, as Minister.

EP A document with which I am sure you are familiar is my book Politics and Medicine, published first in 1967 , second edition 1977 , which

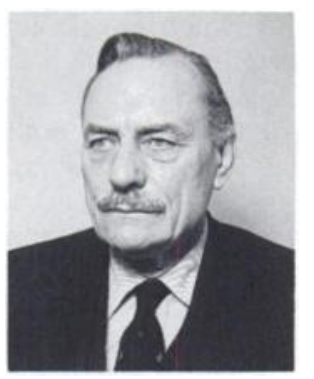
to general astonishment the present owners of the copyright, who are successors to Pitman Medical, have allowed to go out of print. I am sure it is in Politics and Medicine that I referred to the curious fact that a large majority of the individuals who were Ministers of Health in the pre-Secretary of State period were predominantly interested in mental health.

HF Could you say who they were?

EP Well certainly Vosper, Macleod, WalkerSmith, and myself would go into that category, and I think there were others too of whom the same could be said. I will seek to explain it from the paradox that the man who sat in that chair soon realised the vast impact upon a mass of humanity that his own actions and decisions might have, and that this gave him a sense of responsibility where no electoral factor was operative. He found himself under pressure from those who wanted money and effort put into acute medicine and spectacular medical care, and this caused him to lean over backwards towards the forms of care which were unspectacular and particularly those to which no conceivable electoral weight attached. I suppose that was the psychological reason, though I soon found others, why Broadmoor became my personal pet, as Minister.

HF Why was that?

EP If I wasn't on Broadmoor's side, nobody would be. If I didn't order money to be spent on it, nobody was going to press for it. There is therefore the paradoxical effect upon a politician of standing at a point where he leans against the political bias to which he is professionally subject. From the start, I was biased towards the provision for mental care. Certainly, in my extensive tours over the three and a quarter years that I was Minister, and in the public occasions in which I took part, such as opening of hospitals, mental health got more than its proportionate share. I have to admit that in my own case the bias was, if one ought to make such an admission, specialised towards mental handicap or subnormality; for I discovered that it was the one element in the National Health Service which really 'got me going'.

\section{HF Why?}

EP This is just something that happens to a person. I certainly never felt any repugnance towards the care of the mentally handicapped, and found no difficulty in understanding the dedication of the self-selected people who worked on that side. I remember, it was probably in Whitchurch Hospital, outside Cardiff, my officials saying to me "Minister, you won't want to go to such and such a ward; I think you will find it too distressing". Well, that was a challenge, and I did go and I didn't so find. I always had this overwhelming sense, that the patients, and Plato, and I were all on the same side.

\section{HF Plato?}

EP We were all homo sapiens, and even a failed homo sapiens is homo sapiens.

We are being anecdotal at the moment, and I don't intend to go on being anecdotal, though anecdote, talking as a historian to another historian, is an ingredient of history. Part of my ioncern over Broadmoor was to confirm its new character as a hospital, instead of a branch of the prison service.

I think the transfer took place in 1959 - anyhow, it was very recent in my time: it had actually happened under my predecessor, Walker-Smith. I was anxious that as far as possible, it should be made helpful to the hospital, that it was now part of the Health 
Service. One of the ways I sought to contribute to this was the replacement ot the prison warders' uniform by a different uniform. It had to be a uniform and it had to be recognised; nevertheless it must be distinctively not a warder-type uniform. I think it is probably by now an open secret that it was designed for me at my request by Hardy Amies, who is a friend of mine.

In 1960 a Minister with this bias coincided with a department which, having emerged from the legislative business of seeing through the Mental Health Act 1959, wanted to go on to do something about the mental hospitals. It was not merely a coincidence between the time and the individual Minister. There was a double conjuncture. For the first time since 1939 , as a result of a commitment undertaken at the 1959 General Election, the government authorised what, in terms of those days, was massive capital expenditure upon new hospital building over the following ten years. This meant that immediate leverage to a reorientation of mental health care could be given by the Hospital Plan. It was an ambition which I gave voice to in a speech which became notorious, the one about "the water towers brooding over the landscape".

HF I was there, I heard it. I think it really shattered everyone because hardly anyone, although change was in the air, really thought there was going to be an end to the mental hospital. But you clearly, in your own mind, had formulated this plan - that the mental hospital system would end.

EP I think that is an overstatement, unless you overload the word 'system'. I said that the mental hospital system would be right at about half the load it was attempting to cope with. A reduction of that load would be brought about by big physical as well as medical changes, and the more physical change there was, the better.

This hangs together nicely with what I said earlier, that this was really the only side of the Health Service in which I was emotionally involved. I remember a visit to St Andrew's Hospital, Northampton (not an NHS Hospital) which deeply impressed me right at the beginning of my term. I also remember bad behaviour on my part on a visit to a certain other hospital. It must have been in my third year as Minister. We had time to spare after completing our programme in the town and, quite wrongly and naughtily, I said let us go to St So-and-So, and we turned up at 6 o'clock in the evening. It is a good time to visit a mental hospital. If there is anything wrong in a hospital, you will know it at $6 \mathrm{pm}$.
HF Could I ask you what did you see?

EP The unnecessarily low grade of the minor furnishings of the wards and an atmosphere which expressed a wrong attitude towards the patients. Not having a splendid new piece of equipment is quite different. I am conscious, in speaking about St So-and-So, that I behaved naughtily both in visiting unannounced, and in the order, which I gave afterwards, that I wanted a monthly report on my desk about what was being done there. This was subsequently degraded, at an official's request, to a three-monthly report, to which I finally agreed.

HF How long did you get the reports for?

EP I think about six months, and then I was sufficiently satisfied that the message had gone home. I suppose there must be something to be learned from the fact that although I am desperately anxious to get to talking about the Hospital Plan, I am constantly held up by anecdotes. So I will tell you my anecdote about Rauceby mental hospital in south Lincolnshire.

I was driving away in my official car with the Regional Chairman and the Senior Administrative Medical Officer (SAMO), and my driver said to me, "wonderful herd of pigs they've got there". He must have known exactly what the result would be. "Pigs", I said, "you must be seeing double! There are no longer any pig herds in any mental hospital in the whole of the service". "Well, sir", he said, "I don't know. I've seen 3000 there, and there were some prize ones amongst them too, which they showed me." By this time, the most violent electrical signals were coming from behind me in the car, from both the Chairman and SAMO. Afterwards it transpired that, in fact, a false return had been made and a wrong assurance given in good faith. The discontinuance of the farms was a significant symptom of the reorientation that was being attempted in the mental hospitals. In fact, this one was carrying on in the old ways, where the most attractive job on the Hospital Committee was to be Chairman of the Farm Committee.

My driver, who drove me on most of my tours, made a practice, which he soon realised I did not frown on, when there was a two or three-hour visit to a hospital, that he would not just sit reading and smoking in the car, but do his own tour of the hospital. Sometimes, when I was in conference, I would catch a glimpse of this figure crossing my line of vision. This is again a bad story to tell, because it suggests the one thing no Minister should 
ever indulge in, and that is espionage! But itdid enable me to see a hospital from two sides at once.

I am sure you will have encountered in a speech of mine, the story of the Minister and the HS10?

HF No I don't remember that.

EP Well, the HS10 was a complete record of the statistics required from the hospitals, numbers of staff for different departments, etc, etc. There was a space at the bottom for 'beds unused for lack of staff', the total of which was invariably published in a table in the Annual Report of the Ministry of Health. This led to parliamentary criticisms that there were " 12,000 beds in the National Health Service unused for lack of staff." It was some time before I twigged. When I did, I got into the habit on visiting a hospital of folding the HS10 and keeping it in my inner pocket; it was a habit which I later had to discontinue because word of it preceded me. At a critical point on a visit to a hospital, when I had everyone there and the beauty of a hospital visit is that as you go round you accumulate, like an avalanche, more and more people to interrogate - there would be the ward sister, matron, Chairman of the Hospital Management Committee, Hospital Secretary, Regional SAMO, and, with any luck, Regional Board Chairman. When you get them all to the end of a ward, in the sluice room, you're then in the best position for conducting a seminar! This often used to begin as follows: I would ask the Hospital Chairman "I hope you are going to show me the beds which are unused for lack of staff". "Beds unused? There are no beds unused in this hospital." "Well, that's curious" - taking out this HS10 "Mr Secretary, is that your signature?" "Yes Minister". "Well it says 250 beds unused for lack of staff. Can I see them please?" "Oh Minister" says the Hospital Chairman "I know what those would be. Do you see through that window? There used to be another ward there. It was a terrible old ward. We demolished it three years ago. That's where those beds were."

So I realised that the beds were like what Henry II discovered when he called for his baronial returns; they were non-existent. I also began to understand that they were performing a function in the pay and promotion structure of the service and that they were a rotten tooth to be extracted from the Ministry report. This was specially relevant to mental hospitals, since there was a crucial bed figure for the scale on which the matron and others were paid. If you couldn't keep up the patient numbers, you kept up the number of beds, because the scale was based on beds not patients.

It is quite wrong for a Minister to have pals, any more than a Lieutenant Colonel should have pals, so I am again making an admission of default; but there were two such people particularly, apart from Sir George Godber, from whom I received encouragement. One was Stanley Smith, who produced a remarkable reorientation at Lancaster Moor, and the other was Bertie Mandlebrote at Littlemore who had the marvellous axiom, "if short of staff, close beds. If still short of staff, close more beds." It is one of those rough and ready dicta, but I liked it. Sir George was an enormous support to me the more so because he was fully a doctor. He was very interested in mental health services and gave my ideas his backing, though he didn't indulge the same bias.

Now let me try to escape at last, though I fear I might not totally, from anecdotes and take down those two bound volumes - the Health and Welfare Plan (1963) and the Hospital Plan (1962). The rule of thumb established was that, given the altered alignment and the reorientation of mental care, given the progress in chemical therapy and given the intended greater stress upon community care, it should be the aim to halve the patient population of institutional mental hospitals. We were working consciously to that role in drawing up those rather remarkable tables, area by area, which are the feature of the Hospital Plan.

There were two features affecting mental health - one was to aim at a reduction of the overall total institutional care, and the second was to modernise and replace it, and the two operations had to be dovetailed. You could not satisfactorily do the one without the other. If one was going to build a psychiatric element into the district general hospitals, the concept on which the plan was in general based, then very considerable rebuilding work had to be done in institutional mental hospitals. I remember how reluctant we all were, for example, to complete the last old-fashioned block at Balderton. It was a huge hospital, and before the war all but one of the wings had been built. I went to open the last wing, explaining that we ought not to be doing this at all. That was the speech in which I said that building a mental hospital is more like building a cathedral than any other human activity. Its only justification is the same as that for building a cathedral.

I am making the point that the three mental health objectives were fed logically into the 
Hospital Plan; these were improvement of quality, reduction of institutional care, and transfer into community care. I have to admit that at that stage, our views on community care were hazy. I think there was the assumption that somehow a natural suction would operate. Anyhow, the tools of the job we were doing were bricks and mortar: it was a capital investment job. I remember myself sitting in Savile Row one night, going through the tables of plans; for I did not just pass the tables, I was active in compiling them and in relating them to the financial estimates. I forget which the region was, but I said to myself "We are not putting enough into the care of mental disability in this region", and then I actually remember shifting half a million (which was a great amount in terms of capital in those days) from other places and putting them into the mental health column. I said to myself "Boy, you'll never do that again in your life. This is the 'stroke of the pen' that you've heard about".

In the sphere of mental health, of course, we were not up against the bogey which haunted us in the rest of the hospital service, which was the closing of hospitals. It is all very well to build a new district general hospital, but then you are faced with taking out that which has been replaced. I remember the act of genius whereby in a cabinet committee, my predecessor, Iain Macleod, said you must not refer to closing hospitals. You must use the phrase "that work done in the following hospitals will be done more effectively etc, etc" and that was the formula we used. I was never actually allowed to do what I wanted and have an official ceremony to close a hospital. I tried to do it with Shadwell, and nearly got the Department to agree to set up a formal closing ceremony, with the mayor and all the dignitaries and so on, in which I would close the door and formally turn the key. You see, I wanted to symbolise the fact that we were replacing not merely adding.

Now I come to the main anecdote, which will take us into this other document 'Health and Welfare'. The morning after we had published the Hospital Plan, I got the old team - the Chief Medical Officer, Permanent Secretary, and Deputy Secretary and so on together in my room for a conference, and said, "Now we start, don't we, on our Health and Welfare Plan? We must get out a plan in first draft for the successor document, which I want to publish in January 1963." I could see this was not going down at all well; I said "What's the matter?" "Well, they said, you see, it's all for the local Health Authorities and we don't know what they've been doing." Said I, "There is an easy remedy for that; we will go and find out." What we did, in fact, as the basis of this plan, was to carry out an exploration of community care, what was happening, and what was intended, in each of the 144 or (if you counted the Scilly Isles) 145 local health authorities which there were in England and Wales. It had an incredible effect upon the relations between local health authorities and the Department and also between local health authorities and their officials. Officials who previously had been of small importance in their respective authorities suddenly discovered they were the heroes of the hour, and had to be invited to the mayor's lunch with the Minister to explain what was happening in the community services in that local health authority. It also had a valuable effect upon the relationship between the local health authorities and the Ministry. Here was the Ministry coming to the local health authorities and saying "Look, tell us what you are doing and what it is you are intending to do in the future, because we are going to put it all together, and then we shall see if we can make a general picture. You know, we are really in your hands in this way." Here then was something in which there was parity of esteem between the Ministry and the local health authorities; and their Medical Officers of Health, who then still existed and had not yet been unfortunately destroyed, were of course kings of the castles.

There was tremendous goodwill behind the whole operation. The collective intention was set out in a form deliberately designed to match the Hospital Plan, and it contained a survey of what was happening in each authority. We believed that this should become the basis for the capital injection agreed between central government and local government into these local community services. Said I, "It is no use our having a Hospital Plan which presumes this, unless it is going to happen". That, of course, is more or less the point at which my evidence terminates. The Health and Welfare plan was published in April 1963, and I departed in the October. I was not, therefore, a witness to the inherent structural difficulties of combining central government finance of the development of a hospital service (which is difficult enough) with the development of community care to interlock with it. It is not really, in my view, a problem which can be solved organisationally. There are some problems you can solve by organisation, but I don't believe this is one of them. It is like the problem 
of the relationship between general practice and hospital medicine. No amount of structure and committees is going to make it work unless those concerned jolly well want it to. I am much afraid that the deteriorating relationship between central and local government has held back the community development side of this picture.

It is very easy, of course, for a Minister of Health to regard community care as a cheap option. I never had that delusion. I always knew that community care was a dear option. The cheapest thing is an institution: to put people into an institution, is the cheapest manner of getting rid of them. The more intensive, the more expensive; and community care is by definition intensive care. There has to be a far higher staff ratio, a far higher non-patient to patient ratio, if it is going to work. Of course, that intensifies the difficulty of keeping up a continuous and coherent motivation on the part of local health authorities, which have been severely unsettled by reorganisation and financial changes of all kinds in the last 15 years.

HF When the Hospital Plan was published, it clearly embodied the idea of the district general hospital psychiatry department as the hospital base of the mental health services?

EP Whether I would have gone as far myself with the use of the word "base" I don't know. I was not hostile to the specialised mental hospital I had the best relations with the Maudsley but I don't think I would have been doctrinaire enough to say that in any area, the psychiatric department of the general hospital should be the basis of the service.

But there is one respect in which this witness of yours is in the clear. And that is that after 1963 , by a definite decision, he took no further interest in the hospital service. He has refused to undertake hospital engagements or speak to medical bodies, with only one or two exceptions, quite deliberately since.

The move of psychiatry to district general hospitals was the sort of concept which a lay
Minister, satisfied that it was the professional advice he was given, should not challenge. There was no input from me on that question, though I have probably been linked more closely with the demise of the mental hospital system than I realised.

So far as capital was concerned, I had a very good relationship with Chancellor of the Exchequer Selwyn Lloyd, and it was agreed that $£ 500$ million on capital account should be kept separate from the money required for running the service. We worked with the Treasury and fitted in with their projections over 15 years, though only ten years' figures appeared in the Plans' tables, and only the first five years were fully committed. This time-table was kept to for at least the first two years.

HF There were two criticisms of the Health and Welfare Plan-that it was not co-ordinated with the Hospital Plan and that local authorities were not obliged actually to carry out the plans they produced.

EP If you have local government, there is bound to be a division of impetus and responsibility. It was not regarded then as possible to establish a one-to-one ratio between hospital and community activity. There was an element of propaganda in the Plan, though I hoped the local authorities would fully participate. They had a substantial degree of financial autonomy, and it was necessary for them to raise $50 \%$ of the cost of community services from rate money. They hadn't failed to respond on welfare - providing old peoples' homes; there was much local enthusiasm and pressure for that.

HF Was there less enthusiasm and pressure for mental health services?

EP I can't really answer that, because after I had drawn the picture, I went from the Ministry. But there was also an objective of demolishing the workhouses - having no more workhouse accommodation, and I put the screws on local authorities to keep up the impetus for that. I actually visited the last one that was still in use; it was in Newport, Isle of Wight. 